ks. Grzegorz Leszczyński

\title{
Zawarcie małżeństwa z przyczyn całkowicie obcych życiu małżeńskiemu
}

Istnieją pewne motywy, korzyści i subiektywne cele, które w zjawisku symulacji uprzedzają pozytywny akt woli wykluczający małżeństwo, jakiś jego istotny przymiot lub jego istotny element. Dla celów dowodowych są one bardzo ważne, ponieważ, choć same w sobie nie są pozytywnym aktem wykluczenia, wyjaśniają scenerię biograficzną, która w sposób rozumny pozwala zakładać możliwość zaistnienia pozytywnego aktu wykluczenia. Motywacje te jednak mogą wpłynąć na kontrahenta albo w sposób pozytywny, stając się przyczyną zawarcia małżeństwa (causa celebrandi), albo w sposób negatywny, stając się przyczyną wykluczenia małżeństwa, istotnego przymiotu lub elementu tego małżeństwa (causa simulandi)ํ. I tak ta sama motywacja, jaką jest np. uczuciowy związek z kochanką, może pobudzać do prawdziwego

1 Por. Sent. coram Ewers z 19.04.1972 r., RRD 64 (1972), s. 181. Czytamy tutaj: „Quapropter confundenda non est simulationis causa cum motivis quae aliquem ad contrahendum induxerunt: 'haec enim optime stare possunt cum vero matrimonio, immo plerumque dant causam contractui, uti sunt libertatem ope coniugii consequi, etc., dummodo praevalentem consensum in nuptiis comitentur et illum non excludant' [...]. Denique, una eademque causa nequit motivum praebere 
małżeństwa, ponieważ kontrahent uważa, że jego nowy stan małżeński posłuży mu jako możliwość zerwania więzów łączących go z inną osobą, może jednak stać się przyczyną symulacji, gdyż kontrahent wykluczy prawo swojej współmałżonki do wyłączności aktów seksualnych, z powodu istniejącej relacji z inną osobą ${ }^{2}$.

Zawieranie małżeństwa z przyczyny całkowicie obcej życiu małżeńskiemu zwraca uwagę na przyczyny, które mogą stanowić zarówno tzw. causa celebrandi, jak i causa simulandi. W pierwszym rzędzie nakazuje jednak zastanowić się nad tym, czym jest życie małżeńskie i jakie są jego charakterystyczne elementy, by móc określić najpierw przyczyny, które nie są obce życiu małżeńskiemu w celu przeciwstawienia im tych, które nazwiemy obcymi życiu małżeńskiemu.

\section{1. Życie małżeńskie}

Zgodnie z nauczaniem Kościoła, zawartym w dokumentach Soboru Watykańskiego II, jak i zgodnie z określeniem małżeństwa podanym przez prawodawcę w kan. 1055 § 1 Kodeksu prawa kanonicznego z 1983 roku [dalej: KPK] przedmiotem formalnym zgody małżeńskiej jest wspólnota życia mężczyzny i kobiety. Tak określony przedmiot zgody wynika z samej natury małżeństwa3. Sobór Watykański II w konstytucji Gaudium et spes, nr 48 stwierdza, że głęboka wspólnota życia i miłości małżeńskiej

ad contrahendum et simul ad simulandum, cum sibi invicem haec contradicant et ideo ex eadem causa oriri non possint".

2 Por. P. J. Viladrich, Konsens matżeński. Sposoby prawnej oceny i interpretacji w kanonicznych procesach o stwierdzenie nieważności matżeństwa, Warszawa 2002, s. 271-272.

3 Por. J. F. Castaño, Il Sacramento del matrimonio, Roma 1992, s. 120-121. Castaño, pisząc o przedmiocie zgody, dokonuje rozróżnienia między przedmiotem formalnym quod, który określa jako foedus irrevocabile, oraz przedmiotem formalnym quo, który sprowadza się do przyczyn powodujących zawarcie przez nupturientów związku małżeńskiego, takich jak miłość czy zafascynowanie drugą osobą. 
powstaje na mocy przymierza małżeńskiego, czyli nieodwołanej zgody osobowej. Użyte przez sobór sformułowanie „głęboka wspólnota życia i miłości” oznacza, że małżeństwo nie może być rozumiane jedynie $w$ aspekcie życia seksualnego, gdyż jego wymiar dotyczy różnych sfer wspólnego życia, takich jak: sfera duchowa, społeczna czy kulturowa. Jest to ponadto wspólnota oparta na miłości, w której elementem niezwykle istotnym jest wzajemne doskonalenie się małżonków ${ }^{4}$. Z takiego rozumienia małżeństwa wynika również spojrzenie Kościoła na główne cele małżeństwa. Zrodzenie potomstwa, uważane do czasu soboru watykańskiego II za cel najważniejszy, umiejscowione zostaje w kontekście więzi małżeńskiej oraz miłości, która łączy dwoje ludzi ${ }^{5}$. Personalistyczne rozumienie małżeństwa podkreślone jest przez prawodawcę w sformułowaniu celów tegoż małżeństwa, jakimi są ukierunkowanie na dobro małżonków oraz zrodzenie i wychowanie potomstwa ${ }^{6}$.

Należy zauważyć, że dobro małżonków nie jest rzeczywistością obiektywną, lecz osobową, gdyż możliwą do zrealizowania

4 Por. H. Stawniak, Problem „, bonum coniugum”, „Prawo Kanoniczne” 32 (1989) nr 1-2, s. 108-109.

5 Por. P. Moneta, Il matrimonio, w: Il diritto nel mistero della Chiesa, t. 3, Roma 1992, s. 176. Autor pisze: „Per contro, se non un ridimensionamento, ne è scaturita una più equilibrata valutazione della finalità procreativa del matrimonio, tradizionalmente considerata come scopo primario e, in un certo modo, giustificativo (nel quadro di una visione troppo pessimistica della sessualità umana) dell'unione coniugale. Viene così posta in evidenza la stretta connessione che intercorre tra la procreazione e l'amore coniugale, che si apre naturalmente alla generazione di una nuova vita e trova in essa il suo più vero coronamento e il suo più pieno significato umano e spirituale, rendendo i coniugi cooperatori ed interpreti dell'amore di Dio Creatore".

6 Zob. W. Góralski, Znaczenie prawne zwrotu „bonum coniugum” w kan. 1055, par. 1 kpk, „Ius Matrimoniale” 5 (11), 20oo, s. 43-62; G. Leszczyński, Pojęcie „bonum coniugum” w prawie małżeńskim Kościoła, „Śląskie Studia Historyczno-Teologiczne" 36 (2003) z. 1, s. 101-115. 
jedynie przez osoby współmałżonków. Co więcej, nie jest to dobro, które jest dobrem abstrakcyjnym, gdyż jest dobrem właśnie dla konkretnych osób, które decydują się na stworzenie wspólnoty życia ${ }^{7}$ Przekazanie małżonkowi prawa do własnej osoby zawiera nie tylko aspekt fizyczny, ale przede wszystkim emocjonalny i duchowy. Winno być rozumiane w kontekście całej osoby i stać się przezwyciężeniem własnego egoizmu w celu otwarcia się na dia$\log \mathrm{z}$ drugą osobą. Małżonkowie oddają sobie nawzajem prawo do siebie w sposób całkowity, nie dopuszczając jakichkolwiek wyjątków. Każdy wyjątek byłby bowiem zaprzeczeniem całkowitego oddania się w sensie ostatecznym i wyłącznym ${ }^{8}$.

Małżeństwo jest rzeczywistością, która pozwala małżonkom wzrastać w doskonałości osobowej i poprzez to stawać się dobrem dla drugiej osoby. To dobro wspólne małżonków oparte jest na całej gamie wartości umożliwiających wzajemne doskonalenie się w relacji interpersonalnej, wartości uczuciowych, intelektualnych, ekonomicznych, tych o charakterze kulturowym, jak i przede wszystkim duchowym. Chodzi tu więc zarówno o wspólnotę w sferze seksualnej, jak i w codziennym przeżywaniu wspólnych problemów, trudności, które pozornie mogą się wydawać dalekie od tworzenia wspólnoty, w praktyce przezwyciężane wspólnym wysiłkiem taką wspólnotę ubogacają i zbliżają do doskonałości ${ }^{9}$.

Przekazanie prawa w stosunku do siebie wymaga od małżonków ukierunkowania ich wspólnoty na drugi cel, jakim jest zrodzenie

7 Por. R. Bertolino, Gli elementi costitutivi del „bonum coniugum”: stato della questione, w: Il „bonum coniugum” nel matrimonio canonico, Città del Vaticano 1996, s. 18-19.

8 Por. P. A. Bonnet, Il „bonum coniugum” e l'essenza del matrimonio, w: Il „bonum coniugum" nel matrimonio canonico, Città del Vaticano 1996, s. 127-128.

9 Por. R. Bertolino, Gli elementi costitutivi del „bonum coniugum”: stato della questione, dz. cyt., s. 29. 
i wychowanie potomstwa. Sposobem realizacji owego ukierunkowania jest gwarancja aktów małżeńskich współżycia seksualnego otwartych na nowe życie ${ }^{10}$.

Głęboko personalistyczna wizja małżeństwa, obecna zarówno w nauczaniu Soboru Watykańskiego II, jak i w sformułowaniu kan. 1055 § 1 KPK znajduje swoje odzwierciedlenie w określonych w kan. 1056 tego kodeksu przymiotach małżeństwa. Przymiot jedności małżeńskiej, o którym traktuje kan. 1056 § 2 KPK, oznacza, że węzeł małżeński jest jeden i wyłączny, gdyż łączy tylko jednego mężczyznę i jedną kobietę. Dlatego przymiotowi jedności sprzeciwia się jakakolwiek forma poligamii" ${ }^{11}$ Owa monogamiczność, czy inaczej jedność i zupełność węzła małżeńskiego, jest źródłem wyłączności i wierności między małżonkami ${ }^{12}$. Oznacza to, że jedność małżeństwa wymaga wzajemnej wierności małżonków. Co więcej, jedność i wierność małżonków są ze sobą złączone nierozdzielnie. Jakkolwiek jednak jedność stanowi przymiot małżeństwa, wierność przynależy do jego istoty ${ }^{13}$.

Nierozerwalność małżeństwa jest przymiotem, który polega na tym, że ważnie powstały węzeł małżeński nie może być rozwiązany. Przymiot ten wyklucza możliwość zawierania małżeństwa jedynie na jakiś czas. Nierozerwalność małżeństwa wynika z samego pojęcia małżeństwa. Skoro małżeństwo jest głęboką wspólnotą życia i miłości, to jego nietrwałość byłaby zaprzeczeniem dogłębnego i całkowitego oddania się dwojga osób. Nierozerwalność

10 Por. L. Świto, „Exclusio boni prolis” jako tytuł nieważności małżeństwa, Olsztyn 2003, s. 30-31.

11 Por. S. Biskupski, Prawo matżeńskie Kościoła rzymskokatolickiego, Warszawa 1956, s. 47-49.

12 Por. G. Leszczyński, Istotny element matżeństwa jako przedmiot symulacji częściowej, „Ius Matrimoniale” [dalej: IM] 12 (18) 2007, s. 88.

13 Por. M. Wegan, L'esclusione del „bonum fidei” nella più recente giurisprudenza della Rota Romana, „Apollinaris” 61 (1988), s. 96-97. 
jest wpisana w istotę małżeństwa i odnosi się do wszystkich zawierających małżeństwo w każdym miejscu i w każdym czasie ${ }^{14}$.

Reasumując, należy stwierdzić, że przedmiotem formalnym zgody małżeńskiej jest małżeństwo, czyli wspólnota życia i miłości, ukierunkowana na dobro małżonków oraz na zrodzenie i wychowanie potomstwa, oparta na jedności, wzajemnej wierności małżonków oraz nierozerwalności. Z tego względu można stwierdzić, że przyczyna właściwa zawarcia małżeństwa winna uwzględniać koncepcję małżeństwa ze wskazanymi wyżej celami i przymiotami. Co jednak się dzieje, gdy kontrahent zawiera małżeństwo z przyczyn innych, niż te zawarte w koncepcji małżeństwa, o której mowa?

\section{Symulacja zgody małżeńskiej}

Wiadomo, że człowiek, nadużywając znaków czy słów, jest zdolny oznajmiać coś, co nie jest prawdą w jego wnętrzu. Zewnętrzne znaki czy słowa nie zawsze odpowiadają bowiem wewnętrznej woli człowieka, z kolei wewnętrzna wola nie zawsze znajduje swoje uzewnętrznienie w postaci ludzkich reakcji, słów czy znaków. W konsekwencji w postępowaniu człowieka można zaobserwować znaki puste, czy też słowa puste, niemające ciężaru w postaci rzeczywistej woli ich wyrażenia. Znak zewnętrzny pozbawiony swojej wewnętrznej treści jest znakiem pustym, wyrażającym obecną w danej osobie dezintegrację znaku i woli ${ }^{15}$.

Oznacza to, że osoba zawierająca małżeństwo może je symulować, czyli wyrażać za pomocą znaków i słów coś, czego jej wola nie chce. Zawierając małżeństwo, może bowiem wyrażać zgodę małżeńską jedynie pozornie w rzeczywistości, wykluczając samo

\footnotetext{
14 Por. H. Stawniak, Trwałość i nierozerwalność małżeństwa a oczekiwane postawy, IM 9 (15) 2004, s. 31.

15 Por. P. J. Viladrich, Konsens matżeński..., dz. cyt., s. 263.
} 
małżeństwo albo któryś z jego istotnych przymiotów lub elementów. W zjawisku symulacji istotne jest to, aby osoba dopuszczająca się symulacji wiedziała, co wyklucza i chciała to wykluczyć i aby to coś należało to istotnej struktury małżeństwa. Ważne jest, by wyrażenie konsensu, jako znak zewnętrzny, zostało istotnie sfałszowane, choć nie ma znaczenia dla skutków symulacji to, czy podmiot zna naturę i skutki prawne symulacji jako tytuł nieważności ${ }^{16}$. Czy jednak zawsze kontrahent zawierający małżeństwo, np. jedynie dla celów zewnętrznych, towarzyskich czy nawet dla osiągnięcia określonego celu w postaci bycia mężatką lub mężczyzną żonatym, to małżeństwo symuluje? Innymi słowy - czy przyczyna obca życiu małżeńskiemu wywołuje koniecznie symulację małżeństwa bądź jego istotnych przymiotów lub elementów?

Odbywający się 1980 roku Synod Biskupów zwrócił uwagę na konieczność istnienia u kontrahentów przynajmniej minimalnej intencji zawarcia małżeństwa sakramentalnego. Jak stwierdził synod owa minimalna intencja istnieje wówczas, gdy kontrahenci proszą o celebrowanie sakramentu małżeństwa z powodów czysto religijnych. W przeciwnym wypadku, jeśli czynią to jedynie z przyczyn społecznych, konwencjonalnych czy zwykłej tradycji, należy wymagać od kontrahentów dowodów ich osobistej wiary, która mogłaby usprawiedliwiać złożoną przez nich prośbę dotyczącą celebracji sakramentu małżeństwa.

Tak rozumiana intencja konieczna do zawarcia małżeństwa sakramentalnego, umocniona nauczaniem Synodu Biskupów z 1980 roku, nie znajduje jednak uznania wśród większości przedstawicieli doktryny ${ }^{17}$. Większość z nich twierdzi bowiem,

16 Por. A. Stankiewicz, Pozytywny akt woli przy symulacji zgody matżeńskiej, IM 4 (1999), s. 63.

17 Por. F. Bersini, I cattolici non credenti e il sacramento del matrimonio, „Civiltà Cattolica” 127 (1976) IV, s. 556; U. Navarrete, Matrimonio, contratto e sacramento, „Monitor Ecclesiasticus” 118 (1993), s. 106. 
że wystarczającą do zawarcia małżeństwa sakramentalnego jest intencja zawarcia małżeństwa jako takiego, a więc kontraktu, niekoniecznie w rozumieniu kontrahentów mającego swoją sakramentalną rzeczywistośći ${ }^{8}$. Takie rozumowanie wydaje się uzasadnione, gdyż osoby, które pragną zawrzeć związek małżeński, a przez to wyrażają zgodę małżeńską, czyniąc to w Kościele, w rzeczy samej przyjmują, poza możliwymi wyjątkami, że tak wyrażana zgoda małżeńska będzie miała swoją określoną przez Kościół formę $e^{19}$. Trudno byłoby raczej przyjąć, iż ktoś, kto pragnie zawrzeć małżeństwo w Kościele, odrzuca formę, jaka istnieje. Wydaje się, że takie rozumowanie jest bliskie również osobom, które w praktyce są niewierzące, choć ochrzczone, gdyż zawarcie małżeństwa w kościele i dla nich wiąże się z określoną przez Kościół formą. Stąd, należy sądzić, że intencja zawarcia małżeństwa jest wystarczająca do tego, aby pośrednio uznać istnienie w kontrahentach również intencji zawarcia małżeństwa według tego, co czyni, czy jak czyni Kościół²o.

W przypadku symulacji całkowitej kontrahent nie ma w ogóle woli zawarcia związku, w przypadku symulacji częściowej istnieje wola zawarcia związku, natomiast wykluczony zostaje jakiś istotny element lub przymiot małżeństwa. Rozróżnienie przedmiotu symulacji powoduje, zdaniem Juana J. Garcíi Faildego, konieczność dokonania rozróżnienia między obecnością świadomości u osoby symulującej w przypadku symulacji całkowitej a jej brakiem w przypadku symulacji częściowej. Taki sam podział, zdaniem

18 Por. F. Barberi, La celebrazione del matrimonio cristiano. Il tema negli ultimi decenni della teologia cattolica, Roma 1982, s. 439.

19 Por. Z. Grocholewski, L'errore circa l'unità, indissolubilità e la sacramentalità del matrimonio, w: Error determinans voluntatem, a cura di P. A. Bonnet, C. Gullo, Città del Vaticano 1995, s. 19.

20 Por. M. Mingardi, L'esclusione della dignità sacramentale dal consenso matrimoniale nella dottrina e nella giurisprudenza recenti, Roma 2001, s. 198. 
autora, dotyczy udziału woli zawarcia małżeństwa, która w przypadku symulacji całkowitej nie istnieje, a w przypadku symulacji częściowej, jeśli istnieje, jest wadliwa ${ }^{21}$.

Zauważając zarzuty stawiane samej idei podziału na symulację całkowitą i symulację częściową, należy podkreślić, że taki podział jest jak najbardziej uzasadniony, gdyż istnieje zasadnicza różnica między świadomością symulowania małżeństwa jako takiego a świadomością symulowania, czyli wykluczenia którejś z figur zaprezentowanych w kan. 1101 § 2 KPK w odniesieniu do symulacji częściowej ${ }^{22}$. W przypadku symulacji całkowitej istnieje w podmiocie świadomość symulowania małżeństwa ${ }^{23}$, w przypadku symulacji częściowej, niezależnie od tego, czy ukierunkowana jest ona na jeden z istotnych przymiotów, czy też elementów małżeństwa, taka świadomość niekoniecznie musi istnieć, gdyż podmiot może zawierać małżeństwo w dobrej wierze, nie będąc świadomy, iż symuluje zgodę małżeńską, a przez to zawiera małżeństwo nieważnie ${ }^{24}$.

Współczesny człowiek ukształtowany jest w tzw. kulturze wolnościowej wyrażającej się wysoką tolerancją dla życia w konkubinacie. $\mathrm{Z}$ oczywistych zatem względów wola poligamiczna czy konkubencka może mieć wpływ na przyczynę zawarcia małżeństwa, a nawet przyczynę symulacji tego małżeństwa. Kontrahent może bowiem działać z premedytacją, traktując małżeństwo

21 Por. J. J. García Failde, La nulidad matrimonial, hoy. Doctrina y jurisprudencia, Barcelona 1994, s. 91-92.

22 Por. Sent. coram Stankiewicz z 23.07.1982 r., RRD 76 (1982), s. 478. Czytamy tutaj: „Nam in simulatione totali nupturiens consulto ac sciens meram apparentiam celebrationis nuptiarum unice intendit, cum reapse matrimonium ipsum excludat, dum in partiali simulatione ex optat aliquam coniugii speciem (pseudomatrimonium) suis placitis accomodatam, id est sive consortium haud permanens, sive non exclusivum, sive demum ad procreazionem non ordinatum".

23 Por. Sent. coram Egan z 19.07.1984 r., RRD 76 (1984), s. 479.

24 Por. M. Mingardi, L'esclusione della dignità sacramentale..., dz. cyt., s. 63. 
jako swoistego rodzaju parasol dla relacji z inna osobą lub dla tzw. zachowań wolnościowych.

Wola poligamiczna oznacza pozytywną, aktualną albo wirtualną i nieodwołaną wolę jednego lub obojga kontrahentów zarezerwowania sobie prawa zawarcia innego nowego węzła małżeńskiego, przy jednoczesnym trwaniu pierwszego węzła. Stąd wola poligamiczna jest wolą skierowaną przeciw wyłączności węzła małżeńskiego. Wola konkubencka z kolei polega na zastrzeżeniu sobie prawa do współistnienia węzła małżeńskiego z innymi sytuacjami współżycia intymnego z osobami trzecimi, społecznie uznanymi i będącymi źródłem obowiązków prawnych w relacji do tych osób ${ }^{25}$. Wola konkubencka może zatem stać się kontekstem zarówno wykluczenia jedności węzła małżeńskiego, jak i wykluczenia dobra wierności małżeńskiej, a nawet nierozerwalności małżeństwa. Podobnie tzw. kultura wolnościowa, która tak wpływa na wolę kontrahenta, że popycha go do zawarcia małżeństwa z zastrzeżeniem sobie prawa do prowadzenia życia otwartego, wolnego, niezwiązanego obowiązkiem wyłączności, może stanowić kontekst symulacji zgody małżeńskiej, choćby z powodu wykluczenia dobra potomstwa, zwłaszcza w aspekcie wychowania dzieci $^{26}$.

Owa kultura wolnościowa, wykluczająca wyłączność małżonków względem siebie uniemożliwia osobowe wzajemne oddanie się i przyjęcie małżonków. To wykluczenie skutkuje przekazaniem siebie z jakimś ograniczeniem, a przez to nie może stanowić prawdziwej zgody małżeńskiej, a w konsekwencji i prawdziwego małżeństwa. Jeśli zatem kontrahent nie przekazuje prawa w stosunku do siebie w sposób pełny, przekazuje to prawo jako podzielone $\mathrm{z}$ innymi osobami lub zastrzega sobie korzystanie $\mathrm{z}$ owego

25 Por. P. J. Viladrich, Konsens małżeński..., dz. cyt., s. 329-330.

26 Por. Sent. coram Bruno z 15.06.1990 r., RRD 82 (1990), s. 516-517. 
prawa, wyraża zgodę małżeńską wadliwą, która czyni małżeństwo nieważnym.

Szczególną formą ograniczenia wyłączności małżonków jest denegatio iuris. Termin denegatio iuris oznacza negację prawa współmałżonka przy jednoczesnym braku podmiotu, któremu takowe prawo byłoby przekazywane. Sytuacja taka ma miejsce, gdy kontrahent w momencie zawierania małżeństwa wyklucza możliwość dochowania wierności małżeńskiej swojemu współmałżonkowi, nie przekazując tego prawa, jak to miało miejsce w sytuacji participatio iuris in corpus, żadnej innej osobie, czy też innym osobom ${ }^{27}$. Takie stanowisko przyjmuje współczesne orzecznictwo $^{28}$.

Denegatio iuris znajduje swoje uzasadnienie w tym, że kontrahent nie wyklucza obowiązku wierności po to, aby przyjąć na siebie inny obowiązek, ale po to, by uwolnić się od jakiegokolwiek obowiązku. Stąd osoba dopuszczająca się wykluczenia dobra wierności, jak czytamy w sentencji coram De Jorio z 27 października 1971 roku, nie ma w zamiarze duplikowania czy mnożenia związków małżeńskich, czy też pseudomałżeńskich, ale uwolnienie się od obowiązku, który mógłby wynikać z małżeństwa zawieranego ${ }^{29}$.

27 Por. Sent. coram Stankiewicz z 21.04.1983 r., RRD 85 (1983), s. 179-18o. Czytamy tutaj: „Commutatis verbis: ab exlusionem boni fidei non requiritur «ius amandi detur», sedsufficitut obligatio fideli tatisser vandaereiciatur [...]”.

28 Por. Sent. coram Di Felice z 14.06.1984 r., RRD 76 (1984), s. 463; sent. coram Ferraro z 16.10.1984 r., RRD 76 (1984), s. 521; sent. coram Giannecchini z 28.05.1985 r., RRD 77 (1985), s. 262; sent. coram Jarawan z 15.11.1989 r., RRD 81 (1989), s. 679; sent. coram De Laversin z 26.01.1994 r., RRD 86 (1994), s. 49; sent. coram Defilippi z 27.07.1994 r., RRD 86 (1994), s. 415; sent. coram Giannecchini z 28.03.1995 r., RRD 87 (1995), s. 242; sent. coram Serrano z 22.03.1996 r., RRD 88 (1996), s. 310.

29 Por. Sent. coram De Jorio z 27.10.1971 r., RRD 63 (1971), s. 785. Czytamy tutaj: „Ad rem infrascriptus Ponens animadvertebat in una Romana diei 13 iulii 1968 id tantum homines cerebrosos posse intendere, cum ceteri bonum fidei excludant non ut se illigent cum tertia persona quoque, verum ne cum comparte quidem 
Inną grupę przyczyn stojących u podstaw decyzji małżeńskich mogą być różnego rodzaju zburzenia osobowości, a także różnego rodzaju anomalie psychoseksualne. $\mathrm{W}$ tej ostatniej grupie na szczególną uwagę zasługuje tzw. perwersja seksualna. Perwersja seksualna jest jedną z form anomalii psychoseksualnych, która objawia się anormalnym sposobem zaspokajania popędu seksualnego, będącym jedyną formą przeżywania seksualności. Osobowość zdeprawowana, którą orzecznictwo określa czasem terminem „perwersyjna”, oznacza jednak osobowość ukształtowaną we współczesnym społeczeństwie, otwartym na jakąkolwiek formę miłości, wolną w swoim wyrazie i zachowaniu ${ }^{30}$. Stąd, jeśli ktoś od dawna prowadzi życie niemoralne, nie myśląc nawet o zawieraniu małżeństwa, to w momencie jego faktycznego zawarcia nie dochodzi do refleksji i chęci zmiany życia ${ }^{31}$.

Czasami zatem kontrahent działa z pełną premedytacją, symulując zgodę małżeńską. Czasami jednak zawarcie małżeństwa nie wynika z pełnej premedytacji, ale jest wynikiem współczesnego rozumienia trwałości, wierności małżeńskiej, które w świecie propagującym kulturę wolności i tzw. związków wolnych ${ }^{32}$ mogą być postrzegane jako wartości nieistotne bądź niemożliwe do zachowania w pewnych sytuacjach, zwłaszcza dotyczących słabości człowieka. Takie intelektualne przeświadczenie nie tylko może zdeterminować wolę człowieka na tyle, że będzie on zawierał małżeństwo w błędzie dotyczącym właściwego rozumienia przymiotów, ale może również wpłynąć na wolę kontrahenta przekonanego o tym, że wskutek własnej słabości zachowanie przez niego wierności czy trwałości małżeństwa nie jest możliwe.

obligationem contrahant servandi fidem. Aliis verbis excludentes bonum fidei non intendunt vincula duplicare seu multiplicare, verum ab eisdem sese liberare".

30 Por. Sent. coram Stankiewicz z 14.11.1985 r., RRD 85 (1985), s. 486.

31 Por. J. Grzywacz, Wykluczenie „boni fidei”, „Kościół i Prawo” 3 (1984), s. 224.

32 Por. Sent. coram Ragni z 9.12.1982 r., RRD 74 (1992), s. 595-596. 


\section{Intentio prevalens}

Fundamentalne pytanie, które w tym miejscu należy postawić, brzmi: czy każde małżeństwo zawarte z przyczyn obcych życiu małżeńskiemu jest nieważne? Czy zawsze w tych przypadkach mamy do czynienia z symulacją zgody małżeńskiej?

Każde małżeństwo zawierane jest z określonej przyczyny. Podobnie symulacja ma zawsze swoją przyczynę. Przyczyna symulacji zatem różni się od przyczyny zawarcia małżeństwa ${ }^{33}$. Abyśmy mogli mówić o symulacji zgody małżeńskiej, przyczyna symulacji winna być od przyczyny zawarcia małżeństwa silniejsza ${ }^{34}$. Przyczyna symulacji musi być nie tylko wystarczająco poważna, ale przede wszystkim proporcjonalna w odniesieniu do przedmiotu wykluczenia małżeństwa bądź jego istnego elementu lub przymiotu35. Wskazując na konkretne przymioty, jakie powinna mieć przyczyna symulacji, sentencja coram Bruno z 17 maja 1996 roku mówi, że powinna być ona jasna, pewna, obiektywna lub przynajmniej subiektywnie ciężka oraz przeważająca nad przyczyną zawarcia małżeństwa ${ }^{36}$. Oceniając zatem każdy przypadek, sędzia winien porównać obie przyczyny, upewniając się, że causa simulandi przeważyła wolę zawarcia małżeństwa ${ }^{37}$.

Zagadnienie relacji zachodzącej między przyczyną zawarcia małżeństwa a przyczyną symulacji zgody małżeńskiej związane jest z określeniem intencji przeważającej przy wyrażaniu przez kontrahenta zgody małżeńskiej. Nie chodzi, co należy podkreślić,

33 Por. Sent. coram De Laversin z 10.11 .1992 r., RRD 84 (1992), s. 540.

34 Por. Sent. coram Ewers z 19.04.1972 r., RRD 64 (1972), s. 18o. Czytamy tutaj: „Causa simulationis autem est ratio qua quis matrimonium contrahere positive nolens aut non ita seu essentialibus qualitatibus non praeditum, tamen inductus fuerit ad proferendum ore quod corde non teneret".

35 Por. Sent. coram Pompedda z 21.01.1972 r., RRD 64 (1972), s. 26.

36 Por. Sent. coram Bruno z 17.05.1996 r., RRD 88 (1996), s. 389.

37 Por. Sent. coram Bruno z 12.03.1993 r., RRD 85 (1993), s. 146; L. Świto, „Exclusio boni prolis" jako tytut..., dz. cyt., s. 95. 
o obecność dwóch aktów woli ${ }^{8}$, ale raczej o wskazanie, czy w momencie wyrażania zgody małżeńskiej, w ocenie kontrahenta, większe znaczenie odgrywały przyczyny zawarcia małżeństwa, czyli causa celebrandi albo contrahendi, czy też przyczyna symulacji, inaczej causa simulandi ${ }^{39}$. Istotne jest bowiem należyte poznanie, jaka była w momencie zawierania małżeństwa intentio praevalens kontrahenta ${ }^{40}$. Jeśli w momencie wyrażania zgody małżeńskiej kontrahent zamierza pozytywnym aktem woli nie przyjąć obowiązku, np. zachowania wierności, i twierdzi, że gotów byłby raczej zrezygnować z małżeństwa, niż zawierać je z obowiązkiem wierności, to należy przyjąć, że zawarł umowę małżeńską nieważnie. Jeśli natomiast kontrahent przewiduje i postanawia, że jeśli w przyszłości będzie miał okazje ku temu, aby złamać obowiązek wierności, to go złamie, małżeństwo jest ważne, gdyż nigdy nie odrzucił on obowiązku wierności małżeńskiej ${ }^{41}$. Podobnie, jeśli kontrahent nie wyklucza pozytywnym aktem woli sakramentalności małżeństwa i zawiera je z intencją tego, co czyni Kościół, należy uznać takie małżeństwo za ważnie zawarte. Nawet jeśli

38 Por. L. De Luca, L'esclusione del „bonum coniugum”, w: La simulazione del consenso matrimoniale canonico, Città del Vaticano 1990, s. 137. Czytamy tutaj: „E noto che la dottrina e la giurisprudenza canonistica sono solite distinguere nei casi della c.d. simulazione due atti di volontà: la voluntas matrimonium celebrandi e la voluntas simulandi, le quali volontà a loro volta presupporrebbero due distinte «causae». Ora, tale distinzione tra le due volontà è puramente teorica, giacché la stessa dottrina e la giurisprudenza canonistiche finiscono per dover riconoscere che la nullità del matrimonio si verifica quando la volontà contraria alla «substantia matrimonii» non si accompagnata soltanto alla «voluntas matrimonialis». Ma «penetri» in essa giacché solo in questo caso se ne produce la distruzione".

39 Por. Sent. coram Sabattani z 13.11.1959 r., RRD 51 (1959), s. 503. Czytamy tutaj: „Inquirendum est ideo utrum matrimonium in sua substantia vitiatum revera praevaluerit, et quidem per positivam intentionem, utrum in aestimatione nupturientis maius momentum habuerint causae contrahendi an simulandi [...]".

40 Por. Sent. coram Funghini z 23.10.1991 r., RRD 83 (1991), s. 607.

41 Por. W. Góralski, Matrimonium facit consensus, Warszawa 2000, s. 302. 
jako osoba niewierząca pragnie po prostu małżeństwa. Podobnie, jeśli przyczyna zawarcia małżeństwa ma charakter estetyczny, społeczny, środowiskowy, ale nie mamy do czynienia z wyraźnym wykluczeniem małżeństwa bądź jego sakramentalności, trudno mówić o symulacji zgody małżeńskiej. Zatem intentio praevalens jest tutaj kluczem do stwierdzenia, czy małżeństwo zostało zawarte ważnie czy też nie. Jedynie wtedy, gdy przyczyna symulacji przeważa nad przyczyną zawarcia małżeństwa, mamy do czynienia z małżeństwem zawartym nieważnie.

Dowodzenie symulacji zgody małżeńskiej nie jest łatwe. Jak słusznie zauważa Martha Wegan, trudno ustalić, czy kontrahent w momencie wyrażania zgody małżeńskiej, miał tak silną wolę wykluczającą, że osiągnęła ona intensywność pozytywnego wykluczenia woli zobowiązywania się, czy jedynie woli niedotrzymania podjętego zobowiązania. Odmowa bowiem tego prawa w teorii ${ }^{42}$ jest z pewnością możliwa, w praktyce jednak, w konkretnym przypadku, dowodzenie staje się bardzo trudne, gdyż idzie o akt czysto wewnętrzny. Stąd w wątpliwościach uważa się zawsze, że miało miejsce jedynie wykluczenie woli wypełnienia zobowiązania, nie zaś wykluczenie zobowiązywania się, konieczne do zaistnienia symulacji ${ }^{43}$.

42 Por. Sent. coram De Jorio z 13.07.1968 r., RRD 6o (1968), s. 555.

43 Por. W. Góralski, Kanoniczna zgoda małżeńska, Gdańsk 1991, s. 175; sent. coram Mattioli z 30.10.1953 r., RRD 45 (1953), s. 642. Czytamy tutaj: „Etiam simulatio de qua nunc, sicut et alius cuiusque generis simulationes, difficilis probationis est, imo difficilioris. Nam, ex una parte, tota quaestio est de actu interno recte exigendo, et, ex altera, recolenda venit distinctio inter obligationem ipsam, et ipsius obligationis adimplementum; iuxtaquam - ut AA. Et iurisprudentia H.S.O. unanimiter docent - simplex propositum foedandi coniugium per adulterium (quod per se obligationis adimplemento contrarium est) consensum substantialiter non vulnerat". 
SUMMARY

\section{Zawarcie małżeństwa z przyczyn całkowicie obcych życiu małżeńskiemu}

Artykuł dotyczy problematyki zawarcia małżeństwa z przyczyn całkowicie obcych życiu małżeńskiemu. Istnieją bowiem pewne motywy, korzyści i subiektywne cele, które w zjawisku symulacji uprzedzają pozytywny akt woli wykluczający małżeństwo, jakiś jego istotny przymiot lub jego istotny element. Dla celów dowodowych są one bardzo ważne, ponieważ, choć same w sobie nie są pozytywnym aktem wykluczenia, wyjaśniają scenerię biograficzną, która w sposób rozumny pozwala zakładać, że istniała możliwość zaistnienia pozytywnego aktu wykluczenia. Kluczem jednak do stwierdzenia, czy małżeństwo zostało ważnie zawarte pod wpływem przyczyny obcej życiu małżeńskiemu jest intentio praevalens. Jedynie wtedy, gdy przyczyna symulacji przeważa nad przyczyną zawarcia małżeństwa, mamy do czynienia z małżeństwem nieważnie zawartym.

Słowa kluczowe: małżeństwo, konsens małżeński, symulacja, intencja przeważająca, nieważność małżeństwa

\section{STRESZCZENIE}

\section{Marriage for reasons wholly alien to marital life}

The article concerns the issue of the title of the marriage for reasons wholly foreign to marital life. There are certain motives, benefits and subjective aims which, in the phenomenon of simulation, anticipate a positive act of will excluding marriage, some essential quality or its essential element. For evidentiary purposes, they are very important because, although they are not in themselves a positive act of exclusion, they nevertheless explain the biographical setting which makes it reasonable to assume that there 
was a possibility of a positive act of exclusion. However, the key to determining whether a marriage was validly celebrated under the influence of a reason for a foreign marriage life is intentio praevalens. Only if the cause of the simulation outweighs the cause of the marriage, then we are dealing with an annulled marriage.

Keywords: marriage, conjugal consensus, simulation, preponderant intention, invalidity of marriage

Grzegorz Leszczyński, Zawarcie matżeństwa z przyczyn całkowicie obcych życiu matżeńskiemu, w: Warunki dopuszczalności do sakramentów, ze szczególnym uwzględnieniem sakramentu małżeństwa, red. Piotr Kroczek, Kraków 2017, s. 25-41 (Annales Canonici Monographiae, 7).

DOI: http://dx.doi.org/10.15633/9788374388153.03 
